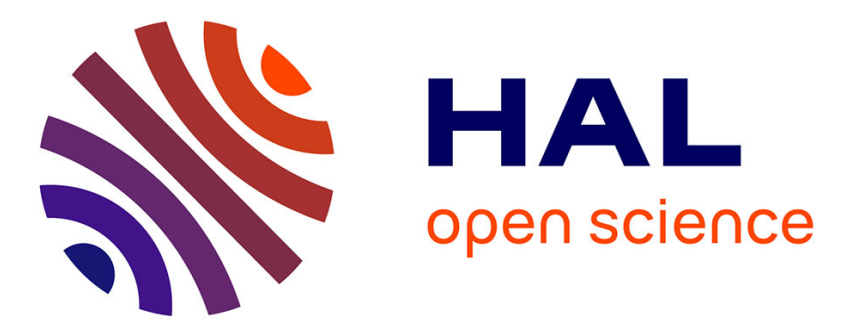

\title{
Biosourced Polymetallic Catalysts: An Efficient Means To Synthesize Underexploited Platform Molecules from Carbohydrates
}

\author{
Vincent Escande, Tomasz Olszewski, Eddy Petit, Claude Grison
}

\section{- To cite this version:}

Vincent Escande, Tomasz Olszewski, Eddy Petit, Claude Grison. Biosourced Polymetallic Catalysts: An Efficient Means To Synthesize Underexploited Platform Molecules from Carbohydrates. ChemSusChem, 2014, 7 (7), pp.1915-1923. 10.1002/cssc.201400078 . hal-03148499

\author{
HAL Id: hal-03148499 \\ https://hal.science/hal-03148499
}

Submitted on 15 Mar 2021

HAL is a multi-disciplinary open access archive for the deposit and dissemination of scientific research documents, whether they are published or not. The documents may come from teaching and research institutions in France or abroad, or from public or private research centers.
L'archive ouverte pluridisciplinaire $\mathbf{H A L}$, est destinée au dépôt et à la diffusion de documents scientifiques de niveau recherche, publiés ou non, émanant des établissements d'enseignement et de recherche français ou étrangers, des laboratoires publics ou privés. 


\title{
Biosourced Polymetallic Catalysts: An Efficient Means To Synthesize Underexploited Platform Molecules from Carbohydrates
}

\author{
Vincent Escande, ${ }^{[a, b]}$ Tomasz K. Olszewski, ${ }^{[c]}$ Eddy Petit, ${ }^{[d]}$ and Claude Grison ${ }^{*[a, b]}$
}

\begin{abstract}
Polymetallic hyperaccumulating plants growing on wastes from former mining activity were used as the starting material in the preparation of novel plant-based Lewis acid catalysts. The preparation of biosourced Lewis acid catalysts is a new way to make use of mining wastes. These catalysts were characterized by X-ray fluorescence, X-ray diffraction, inductively coupled plasma mass spectrometry, and direct infusion electrospray ionization mass spectrometry. These analyses revealed a complex composition of metal species, present mainly as polymetallic chlorides. The catalysts proved to be efficient and recyclable in a solid-state version of the Garcia Gonzalez reaction, which has been underexploited until now in efforts to
\end{abstract}

\section{Introduction}

As the pressure on raw materials derived from fossil fuels continues unabated and environmental concerns become ever more pervasive, the chemical industry must increasingly focus on obtaining raw materials from renewable resources. ${ }^{[1]}$ Thus, special emphasis should be put on developing protocols for transforming biomass into fine chemicals and chemicals with high added value. ${ }^{[1,2]}$ There is already a considerable range of chemical building blocks derived from renewable resources, such as 5 -hydroxymethylfurfural ${ }^{[3]} \gamma$-valerolactone, ${ }^{[4]}$ and lactic acid. $^{[5]}$

Because of their high synthetic potential, carbohydrates obtained from plant-derived biomass will make a valuable contribution to green chemistry of the future. ${ }^{[6]}$ The Garcia Gonzalez reaction is a highly valuable route for the synthesis of polyhydroxyalkyl furans starting from carbohydrates (hexoses and

[a] V. Escande, Prof. Dr. C. Grison CNRS-STRATOZ, FRE 3673

Cap Alpha, av. de l'Europe, 34830 Clapiers (France) E-mail: claude.grison@cnrs.fr

[b] V. Escande, Prof. Dr. C. Grison ADEME

20 av. du Grésillé, BP90406, 49004 Angers (France)

[c] Dr. T.K. Olszewski

Faculty of Chemistry, Wroclaw University of Technology Wybrzeze Wyspianskiego 27, 50-370, Wroclaw (Poland)

[d] E. Petit

Institut Européen des Membranes, UMR 5635, CC 047

Place Eugène Bataillon, 34095 Montpellier (France) use carbohydrates from biomass. This methodology was extended to various carbohydrates to obtain the corresponding polyhydroxyalkyl furans in 38-98\% yield. These plant-based catalysts may be a better alternative to classical Lewis acid catalysts that were previously used for the Garcia Gonzalez reaction, such as $\mathrm{ZnCl}_{2}, \mathrm{FeCl}_{3}$, and $\mathrm{CeCl}_{3}$, which are often unrecyclable, require aqueous treatments, or rely on metals, the current known reserves of which will be consumed in the coming decades. Moreover, the plant-based catalysts allowed novel control of the Garcia Gonzalez reaction, as two different products were obtained depending on the reaction conditions.

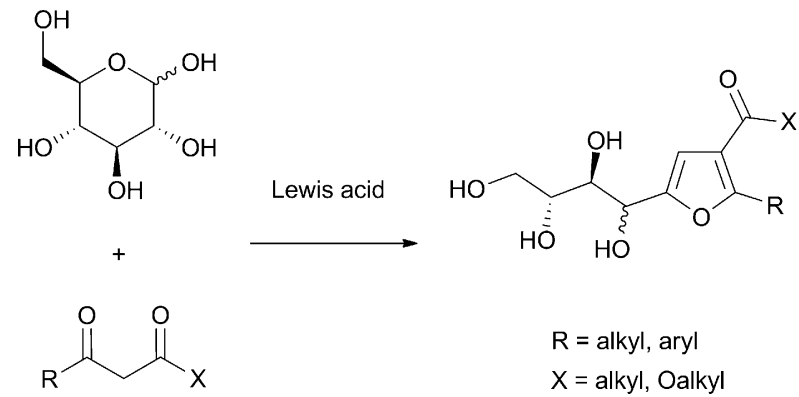

Scheme 1. General concept of the Garcia Gonzalez reaction.

pentoses) and $\beta$-dicarbonylated compounds (Scheme 1), but strangely it seems to have been largely forgotten. ${ }^{[7]}$

By furnishing a number of useful properties including chirality, rigidity, lipophilicity, hydrophilicity, and flexibility in one system, polyhydroxyalkyl furans represent an interesting scaffold or platform molecule for synthetic chemists to use in the preparation of a variety of diverse structures (Figure 1).

Reported examples of their use include the preparation of free furanic acids having a polyhydroxylated alkyl side chain, ${ }^{[7]}$ the synthesis of aldehydes by oxidative cleavage of the polyhydroxylated alkyl side chain, ${ }^{[8]}$ oxidation/reduction of the carbonyl group, ${ }^{[9]}$ and substitution of the terminal hydroxy groups to form oligomers. ${ }^{[9]}$

The Garcia Gonzalez reaction has the potential to meet the modern criteria for green and sustainable chemistry. ${ }^{[10]}$ This transformation is operationally simple, high yielding, and performed under environmentally friendly conditions (by using 
<smiles>[R]NCC(=O)c1cc(C([X])=O)c([R])o1</smiles><smiles>[R]c1occc1C(=O)O</smiles><smiles>[R]c1oc(C(=O)CO)cc1C(=O)O</smiles><smiles>[X]C(=O)c1cc(C=O)oc1[R]</smiles><smiles>CC</smiles>

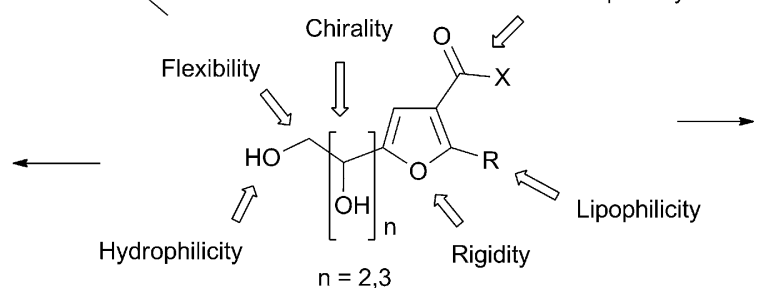<smiles>[R]c1oc(C(C)=O)cc1CO</smiles><smiles></smiles><smiles>[X]C(=O)c1cc(C(C=O)OCC=O)oc1[R]</smiles><smiles>CI</smiles><smiles>[X]C(=O)c1cc(C2OCC(O)C2O)oc1[R]</smiles>

Figure 1. Polyhydroxyalkyl furans as platform molecules for synthetic chemists.

a mixture of $\mathrm{H}_{2} \mathrm{O} / \mathrm{EtOH}$ as the reaction medium); moreover, it requires a moderate temperature and short reaction time. The reaction is catalyzed by Lewis acids such as $\mathrm{ZnCl}_{2}{ }^{[7]} \mathrm{FeCl}_{3}{ }^{[11]}$ and $\mathrm{CeCl}_{3}{ }^{\left[{ }^{[1,2]}\right.}$ However, these classical catalytic systems are unrecyclable, require aqueous treatment, rely on metals, the current known reserves of which will be consumed in the coming decades, ${ }^{[13]}$ and do not permit control of the reaction selectivity (in some cases, the polyhydroxylated alkyl side chain undergoes further cyclization). ${ }^{\left[{ }^{[1]}\right.}$ Owing to the depletion of metal resources ${ }^{[14]}$ and the emergence of new more stringent regulations, ${ }^{[15]}$ new catalysts are required that are inexpensive and that are not based on increasingly scarce metals. ${ }^{[16]}$

Earlier work by our group led to the development of a new range of plant-based Lewis acid catalysts that are derived from nonconventional biomass, that is, metal hyperaccumulator species. Metal-hyperaccumulating plants, or metallophytes, extract trace metals from soil and concentrate them in their shoots. ${ }^{[17]}$ Exploring the utility of these plants led to the development of a phytoextraction technique that offers a means to remove the trace metals from contaminated soils, for example, contaminated mine sites, which cause major environmental problems worldwide. ${ }^{[18]}$ Today, this environmentally compatible process has emerged as the preferred method to reclaim metal-contaminated sites. It is less costly than conventional remediation methods, has a lower environmental impact, and is better accepted by the public. ${ }^{[19]}$ Potential and specific markets exist for phytoextraction, which also offers an alternative source of nonrenewable mineral materials. ${ }^{[20]}$ Field-scale trials of phytoextrac- tion by using the practices of farming systems proved the technology's potential on a large scale. It is now possible to access up to several tons of Ni-rich biomass in the USA and in Europe. As an example, crop yields of the nickel hyperaccumulator Alyssum murale can reach at least $20 \mathrm{tha}^{-1}$ or $400 \mathrm{~kg} \mathrm{Niha}^{-1}$ with ordinary fertilizers and management practices. ${ }^{[21]}$ Similar studies are in progress for zinc hyperaccumulator plants. We estimate that a possible biomass production of $5.2 \mathrm{tha}^{-1}$ would yield $60 \mathrm{~kg} \mathrm{ha}^{-1}$ of $\mathrm{Zn}$, and this is in agreement with the findings of Robinson et al. ${ }^{[22]}$

However, numerous efforts are still necessary to exploit the ability to recover and recycle metals from contaminated biomass and fully develop the economic potential of phytoextraction. Innovative technologies are needed to obtain the full benefit of the remediation process. We have found that the unique polymetallic composition of the catalysts derived from metal hyperaccumulating plants allows them to efficiently mediate a diverse set of reactions to afford valuable products in good yields under mild reaction conditions. ${ }^{[18 c, 23]}$

Herein, we describe the use of a novel plant-based Lewis acid catalyst for the Garcia Gonzalez reaction, an innovation that will be of major interest for green chemistry. The key benefits of the proposed catalytic system are the use of a catalyst of plant origin, the possibility to recycle and reuse it, efficiency in terms of yield, the wide range of its applications, ease of control of the reaction outcome, and mild reaction conditions. 


\section{Results and Discussion}

In this study, we used the two best zinc hyperaccumulator plants, Noccaea caerulescens (Brassicaceae) and Anthyllis vulneraria (Fabaceae), harvested in Les Avinières, a former zinc mining site in Saint-Laurent-Le-Minier, southern France. Both are included in a large program of ecological rehabilitation of this site; they are able to concentrate approximately $120000 \mathrm{ppm}$ of $\mathrm{Zn}$ " in calcinated shoots. ${ }^{[18 c]}$ The plant-based catalysts were prepared by heat treatment of leaves at $400^{\circ} \mathrm{C}$, followed by the addition of $\mathrm{HCl}(1 \mathrm{M})$. The potential of zinc hyperaccumulating plants for plant-based catalysis was based on the total mineral composition of contaminated biomass. X-ray fluorescence (XRF) was used to determine the exact chemical composition of the plant extract that was obtained (Table 1).

\begin{tabular}{|lc|}
$\begin{array}{l}\text { Table 1. Elemental composition of the plant-based catalyst, as estab- } \\
\text { lished by XRF. }\end{array}$ \\
Element & Composition [wt $\% \pm$ standard deviation] \\
\hline $\mathrm{Na}$ & $1.72 \pm 0.021$ \\
$\mathrm{~K}$ & $5.72 \pm 0.078$ \\
$\mathrm{Mg}$ & $1.6 \pm 0.080$ \\
$\mathrm{Ca}$ & $10.3 \pm 0.17$ \\
$\mathrm{Fe}$ & $2.75 \pm 0.063$ \\
$\mathrm{Zn}$ & $6.75 \pm 0.021$ \\
$\mathrm{Cd}$ & $0.19 \pm 0.0026$ \\
$\mathrm{Al}$ & $1.5 \pm 0.014$ \\
$\mathrm{~Pb}$ & $0.44 \pm 0.0029$ \\
$\mathrm{O}$ & $15.97 \pm 0.50$ \\
$\mathrm{Cl}$ & $43.27 \pm 0.23$ \\
\hline
\end{tabular}

The XRF data were additionally confirmed by inductively coupled plasma mass spectrometry (ICP-MS). The mineral analysis clearly revealed that $\mathrm{Zn}$ was the major transition metal $(6.75 \%)$, accompanied by an amount of $2.75 \%$ of Fe. An amount of $1.50 \%$ of $\mathrm{Al}$ was also noted. The reproducibility of the composition of the catalyst was investigated, depending on the localization of the crops. Three different samples of leaves were collected at different points in the former mining site, and their content in Lewis acids was analyzed by ICP-MS after their transformation into the catalyst
(Table 2). Whereas the contents of transition metals ( $\mathrm{Zn}, \mathrm{Fe}, \mathrm{Cd}$ ) and of $\mathrm{Al}$ and $\mathrm{Pb}$ were stable in the samples, larger differences were observed for $\mathrm{Mg}$ and $\mathrm{Ca}$ (see also data in Table 1). However, as the use of hyperaccumulating plants is intended as a source of Lewis acids, and particularly of transition metals, this variability in the $\mathrm{Mg}$ and $\mathrm{Ca}$ content should not compromise the catalytic activity. As a precaution, it is preferable to prepare the catalyst starting from the largest lots of collected plants to homogenize the composition and minimize variation. The biosourced catalyst obtained was characterized by X-ray diffraction (XRD) (Table 3). As the noncrystalline species were

\begin{tabular}{|ll|}
\hline \multicolumn{2}{|l|}{ Table 3. Characterization of the plant-based catalyst by XRD. } \\
Mineral & Formula (simplified) \\
\hline calcium magnesium chloride hydrate & $\mathrm{CaMg}_{2} \mathrm{Cl}_{6}\left(\mathrm{H}_{2} \mathrm{O}\right)_{12}$ \\
anhydrite, syn & $\mathrm{CaSO}_{4}$ \\
potassium zinc tetrachloride & $\mathrm{K}_{2} \mathrm{ZnCl}_{4}$ \\
sylvite, syn & $\mathrm{KCl}$ \\
magnesium phosphate & $\mathrm{MgP}_{4} \mathrm{O}_{11}$ \\
\hline
\end{tabular}

not detected by XRD, the plant-based catalyst was also characterized by direct infusion in electrospray ionization mass spectrometry (ESI-MS) in the negative mode after dilution in water. Metallic species were detected as chlorides and were identified by their isotopic distribution, as described in Table 4 .

The concentration of the solution led to an unusual mixture of mineral species, such as potassium zinc tetrachloride. ${ }^{[18 c]}$ $\mathrm{K}_{2} \mathrm{ZnCl}_{4}$, the sole mixed zinc chloride that was observed, is a masked form of $\mathrm{ZnCl}_{2}{ }^{[18 \mathrm{c}]}$

First, we tested the ability of the plant-based catalyst to catalyze the Garcia Gonzalez reaction starting from D-glucose (1 a) and ethyl acetoacetate ( 2 a) by using different environmentally benign reaction media previously described in the litera-

Table 4. Characterization of the plant-based catalyst by direct infusion mass spectrometry (ESI-). ${ }^{[a]}$

$m / z$ (abundance [\%])

159 (6), 161 (100), $162(2.3), 163$ (93.7), 164 (2.2), 165 (30.1), $166(0.7), 167$ (3.3)

194 (4.7), 196 (80.8), 197 (1.8), 198 (100), 199 (2.3), 200 (48), 201 (1.1), 202 (10.4)

169 (64.7), 171 (100), 172 (5.5), 173 (81.5), 174 (5.3), 175 (39), 176 (1.7), 177 (9.9), 179 (1.1)

211 (2.2), 213 (2.2), 215 (23), 216 (22.8), 217 (64.7), 218 (43.9), 219 (100), 220 (28.3), 221 (77.4), 222

(7.6), 223 (30.6), $224(0.7), 225(5.9)$

$303(48), 304(6.1), 305(100), 306(11.8), 307(88.6), 308(9.6), 309(76.5)$

311 (33.4), 312 (29), $313(100), 314$ (28.2), 315 (76.8), $316(9.1), 317(22.7)$

[a] See the Supporting Information for a comparison of the experimentally observed and predicted isotopic distribution.

\begin{tabular}{|c|c|c|c|c|c|c|c|c|}
\hline \multirow{2}{*}{$\begin{array}{l}\text { Sample of plant-based } \\
\text { catalysts }\end{array}$} & \multirow{2}{*}{$\begin{array}{l}\text { Latitude, longitude data of } \\
\text { sampling sites }\end{array}$} & \multicolumn{7}{|c|}{ Composition [wt $\% \pm$ standard deviation] } \\
\hline & & $\mathrm{Mg}$ & $\mathrm{Ca}$ & $\mathrm{Fe}$ & $\mathrm{Zn}$ & $\mathrm{Cd}$ & $\mathrm{Al}$ & $\mathrm{Pb}$ \\
\hline sample 1 & $43.933031,3.666407$ & $3.76 \pm 0.10$ & $35.81 \pm 0.50$ & $1.80 \pm 0.028$ & $6.57 \pm 0.059$ & $0.35 \pm 0.0040$ & $1.74 \pm 0.049$ & $0.73 \pm 0.0048$ \\
\hline sample 2 & $43.933514,3.667212$ & $4.26 \pm 0.16$ & $31.15 \pm 0.66$ & $1.13 \pm 0.030$ & $4.80 \pm 0.097$ & $1.12 \pm 0.036$ & $1.10 \pm 0.056$ & $0.31 \pm 0.0076$ \\
\hline sample 3 & $43.932737,3.666461$ & $11.68 \pm 0.18$ & $25.75 \pm 0.59$ & $2.95 \pm 0.030$ & $9.65 \pm 0.045$ & $0.063 \pm 0.00060$ & $1.55 \pm 0.088$ & $0.11 \pm 0.00067$ \\
\hline
\end{tabular}


ture. ${ }^{[7,8,11]}$ Initially, the reaction was performed in water/ethanol, but significant leaching of the metallic elements was noted. To circumvent this problem, we attempted to support the plantbased catalyst on montmorillonite K10 and silica gel by using impregnation methodology. ${ }^{[2]}$ Those experiments, however, led to a decrease in catalytic activity. To improve our methodology, we conducted the reaction in the solid phase by following methods previously used by Bartoli et al. ${ }^{[12]}$ Silica gel was used to disperse the catalyst and the reagents. Gentle heating was necessary to achieve total conversion (TLC analysis). Subsequent easy workup was based on washing the solid with ethyl acetate to extract the reaction products (Figure 2). Insolu- considered conceivable for an economically feasible process, one that furthermore may permit reuse of the catalyst. ${ }^{[25]}$

For all reactions, the amount of biosourced polymetallic catalyst was set at $4.0 \mathrm{~mol} \%$ of $\mathrm{Zn}$ or $8.0 \mathrm{~mol} \%$ of the sum $\mathrm{Zn}+$ $\mathrm{Fe}+\mathrm{Al}$. Owing to the complex composition of the catalyst, we chose to focus on $\mathrm{Zn}, \mathrm{Fe}$, and $\mathrm{Al}$, as these elements have the most pronounced Lewis acidity of the elements present in the catalyst and are the most likely contributors to the catalytic activity. Loadings lower than $8.0 \mathrm{~mol} \%$ of the sum $\mathrm{Zn}+\mathrm{Fe}+\mathrm{Al}$ resulted in a decrease in the reaction yield (Table 5 , entry 3 ). In turn, higher loadings did not improve the reaction yield, even after prolonged heating.

Interestingly, if the reaction time was extended beyond $24 \mathrm{~h}$, the formation of an epimeric mixture of desired polyhydroxyalkyl furans $\mathbf{3}$ a-3 $\mathbf{a}^{\prime}$ was accompanied by the formation of cyclization products $\mathbf{4} a-\mathbf{4} \mathbf{a}^{\prime}$, which result from the cyclization-dehydration of the initial products. ${ }^{[26]}$ If the reaction temperature was set at $85^{\circ} \mathrm{C}$, after $24 \mathrm{~h}$ only products $\mathbf{4 a - 4} a^{\prime}$ were formed in almost quantitative yield (Scheme 2). In turn, setting the reaction temperature at $50^{\circ} \mathrm{C}$ gave the controlled formation of polyhydroxyalkyl furans $\mathbf{3} a-\mathbf{3} \mathbf{a}^{\prime}$

bility of the metallic elements of the plant-based catalyst in this solvent was noted. This improved methodology was very efficient (Table 5, entries 1 and 2) and avoided contamination of the reaction products with the metallic residue. Bartoli and collaborators used $\mathrm{Nal}$ as an activating compound, ${ }^{[12]}$ but no such additive was necessary if the reaction was catalyzed by the plant-based catalyst. The choice of conditions was also guided by the outcome of the experiment and was therefore
(Scheme 2). Therefore, the application of the plant-based catalyst enabled easy control of the process by simple adjustments of temperature and reaction time.

Therefore, this biosourced catalyst has unique flexibility and enables the control of the reaction sequence in comparison to "classical" catalysts and conditions, which lead only to one of the two possible products or to a mixture of $\mathbf{3 a - 3} a^{\prime}$ and $\mathbf{4 a -}$ $4 a^{\prime}$.

Additionally, the Garcia Gonzalez reaction of $\mathbf{1}$ a with $\mathbf{2}$ a performed in the presence of only $\mathrm{SiO}_{2}$ led to products $3 \mathrm{a}-\mathbf{3} \mathrm{a}^{\prime}$ in $8 \%$ yield (Table 5 , entry 4 ). Likewise, the use of commercial $\mathrm{ZnCl} / \mathrm{SiO}_{2}$ in the same proportion as in the run with the plantbased catalyst (Table 5 , entry 1 ) gave lower yield and selectivity (Table 5, entry 5). The combination of $\mathrm{Zn}^{\prime \prime}, \mathrm{Fe}^{\prime \prime \prime}$, and $\mathrm{Al}^{\mathrm{III}}$ conveyed the catalytic activity, but with selectivity opposite to that obtained with the use of the plant-based catalyst (Table 5, entry 6). This is in accordance with previously published data, for which only the furan with a cyclic polyhydroxylic chain was 


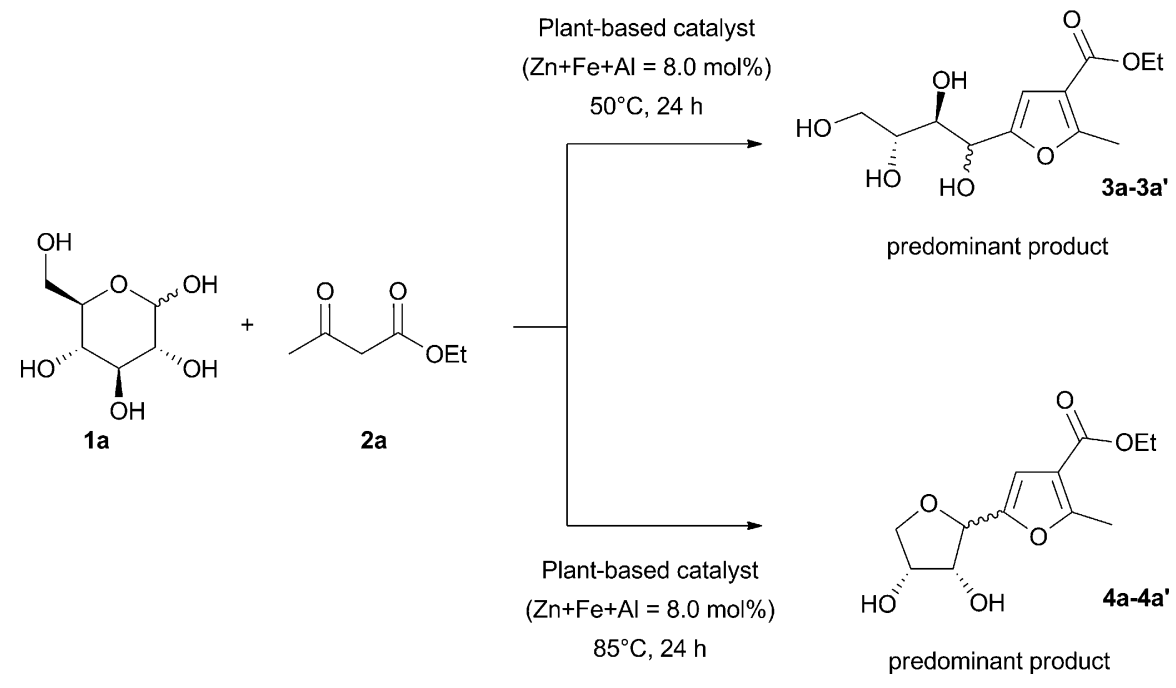

Scheme 2. Controlling the selectivity of the Garcia Gonzalez reaction.

obtained if $\mathrm{FeCl}_{3}$ was used as the catalyst. ${ }^{[1]}$ These results show that the catalytic activity lies in the polymetallic composition and in the original species present in the plant-based catalyst.

Subsequently, the optimized reaction conditions were applied to a selected spectrum of hexoses and pentoses and to $\beta$-dicarbonyl compounds to test the scope of the presented protocol (Table 6). The use of pentane-2,4-dione ( $\mathbf{2} \mathbf{b})$ as the $\beta$ dicarbonyl compound instead of ethyl acetoacetate $(2 \mathrm{a})$ led selectively to expected polyhydroxyalkyl furans $\mathbf{3} \mathbf{b}-\mathbf{3} \mathbf{b}^{\prime}$ in $72 \%$ yield if the reaction was performed at $50^{\circ} \mathrm{C}$ for $24 \mathrm{~h}$ (Table 6 , entry 3$)$. In turn, at $85^{\circ} \mathrm{C}$ only expected cyclization products $\mathbf{4} \mathbf{b}-\mathbf{4} \mathbf{b}^{\prime}$ were obtained in $91 \%$ yield (Table 6 , entry 4$)$. The use of 1,3-cyclohexanedione $(\mathbf{2} \mathbf{c})$ in the Garcia Gonzalez reaction has not been previously reported. In our case, with the use of the plant-based catalyst we obtained cyclization products $4 \mathrm{c}-$ $4 c^{\prime}$ in a low yield of $38 \%$, probably as a result of the known dimerization of $2 \mathrm{c}$ (Table 6 , entry 5). ${ }^{[27]} \mathrm{A}$ reaction with the use of D-galactose (1 b) and pentane-2,4-dione (2 b) did not follow the general pathway and furnished only cyclization products $\mathbf{4 d - 4} \mathbf{d}^{\prime}$ in $\mathbf{9 8} \%$ yield (Table 6, entry 6). As described in the literature, owing to the lack of anchimeric assistance of the $\mathrm{OH}$ group at the $\mathrm{C2}^{\prime}$ position during the cyclization and probably because of steric effects, the two diastereomers were formed with a modest selectivity of $\mathbf{4 d} / \mathbf{4} \mathbf{d}^{\prime}=70: 30 .^{[11]}$ The reaction of pentane-2,4-dione (2 b) with D-mannose (1 c) followed the same pathway and furnished only cyclization products $\mathbf{4} \mathbf{b}-\mathbf{4} \mathbf{b}^{\prime}$ in $90 \%$ yield (Table 6 , entry 7 ). Finally, the biosourced catalyst was found to efficiently mediate the reaction performed with the use of pentoses. Polyhydroxyalkyl furans $3 \mathrm{e}-\mathbf{3} \mathrm{e}^{\prime}$ were obtained in $70 \%$ yield starting from pentane-2,4-dione ( $\mathbf{2} \mathbf{b})$ and D-ribose (1 d) or D-xylose (1 e; Table 6, entries 8 and 9). The lateral chain was too short to undergo cyclization and, thus, only polyhydroxyalkyl furans were obtained.

In the case of cyclic products, the existence of those products as a mixture of diastereomers is well documented. ${ }^{[11,26 a]}$ The ratio of diastereomers observed was moderate owing to the anchimeric assistance of the $\mathrm{OH}$ group at the $\mathrm{C2}^{\prime}$ position or to its absence, depending on the starting carbohydrate. ${ }^{[11]}$ However, in our case, after acetylation of the obtained uncyclized products, analysis by GC-MS revealed two signals with similar $\mathrm{m} / \mathrm{z}$ values corresponding to two diastereomers. This fact was confirmed by ${ }^{1} \mathrm{H}$ NMR spectroscopy, for which the signals were doubled in various proportions, depending on the starting carbohydrate.

To avoid confusion by the formation of cyclic diastereomers, we studied the polyhydroxyalkyl furans obtained from pentoses, in which the lateral chain is too short to undergo cyclization. Starting from D-ribose, two diastereomers were observed by ${ }^{1} \mathrm{H}$ NMR spectroscopy for the products that had the linear polyhydroxyalkyl side chain. The diastereomers were most probably formed by epimerization at the $\mathrm{C} 2^{\prime}$ position (at which the dehydration is favored in the $\alpha$ position to the furan), following the formation of the carbocation by a mechanism proposed by Sánchez and Roldán, ${ }^{[26 a]}$ for which the linear epimers were until now hypothetical (Scheme 3)

To confirm the formation of those epimers with other catalysts, the synthesis was performed with the use of $\mathrm{FeCl}_{3}$ and Dribose as the carbohydrate. ${ }^{[11]}$ Analysis of the reaction product by ${ }^{1} \mathrm{H}$ NMR spectroscopy clearly showed the existence of two diastereomers if the reaction was catalyzed by $\mathrm{FeCl}_{3}$.

The experimental results (Table 6) showed the following trends concerning the proportions of isomerized products: For uncyclized products, epimerization at $\mathrm{C2}^{\prime}$ with rates of 8 to $25 \%$ was observed. In contrast, the rates of isomerization were lower for the cyclized products, as most of the products were observed as $\beta$ isomers (89-99\%). This is probably due to steric effects, as in the $\alpha$ isomer the furan and hydroxyl groups are on the same side of the tetrahydrofuran moiety. Indeed, higher proportions of the $\alpha$ isomer (30\%) were observed only for the cyclized product resulting from D-galactose in which the furan and the vicinal hydroxy group are on opposite faces of the tetrahydrofuran moiety (Table 6, entry 6). From a practical point of view, it should be noted that in each case, the different diastereomers of the uncyclized and cyclized products could be separated by fractional crystallization in ethyl acetate.

To test the potential for recycling and reuse of the catalyst, the catalyst was washed with ethyl acetate, dried $\left(120^{\circ} \mathrm{C}, 5 \mathrm{~h}\right)$, and used in a new run to yield the desired product. As summarized in Table 7, the polymetallic catalyst was used up to four cycles with a marginal decrease in catalytic activity. The batch-to-batch variability of the substrates was monitored by $\mathrm{XRF}$; the mineral composition remained almost the same up to the fourth run. This was determined by comparing the amount 
Table 6. Scope of the presented protocol. ${ }^{[\mathrm{a}]}$

Entry Carbohydrate $\beta$-Dicarbonyl $T\left[{ }^{\circ} \mathrm{C}\right]$

$\underbrace{2}_{2 a}$

$78 \%$

$\underbrace{1 \mathrm{O}}_{\mathrm{OH}}$<smiles>CCOC(=O)c1cc([C@@H](O)[C@@H](O)[C@H](O)[C@H](O)CO)oc1C</smiles>

$\underbrace{\mathrm{O}}_{1 \mathrm{OH}}$

50<smiles>CC(=O)c1cc([C@@H](O)[C@@H](O)[C@H](O)CO)oc1C</smiles><smiles>CC(=O)c1cc([C@@H](O)[C@@H](O)[C@H](O)CO)oc1C</smiles>

$75 \%$

$\underbrace{\mathrm{O}}_{1 \mathrm{OH}}$<smiles>CC(=O)c1cc([C@@H](O)[C@@H](O)[C@H](O)CO)oc1C</smiles><smiles>CC(=O)c1cc([C@@H](O)[C@@H](O)[C@H](O)CO)oc1C</smiles><smiles>O=C1CCCC(=O)C1</smiles>
50<smiles>O=C1CCCc2oc([C@@H](O)[C@H](O)[C@H](O)CO)cc21</smiles><smiles>O=C1CCCc2oc([C@@H](O)[C@@H](O)[C@H](O)CO)cc21</smiles><smiles>CC(=O)CC(C)=O</smiles>
50<smiles>CC(=O)c1cc([C@@H](O)[C@@H](O)[C@H](O)CO)oc1C</smiles><smiles>CC(=O)c1cc([C@@H](O)[C@@H](O)[C@H](O)CO)oc1C</smiles>

7 (c)<smiles>CC(=O)c1cc([C@@H](O)[C@@H](O)[C@H](O)CO)oc1C</smiles><smiles>CC(=O)c1cc([C@@H](O)[C@@H](O)[C@H](O)CO)oc1C</smiles>

$8 \quad{ }_{1 \mathrm{O}}$

9 管 50<smiles>CCCCC(O)c1cc(C(C)=O)c(C)o1</smiles>

$3 \mathrm{e}$ 3e
$77 \%$
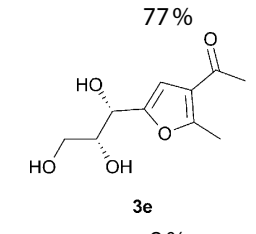

65<smiles>CCOC(=O)c1cc([C@H]2CCCO2)oc1C</smiles><smiles>O[Hg]O</smiles>

$4 a$

$98 \%$

0<smiles>CC(O)C(C)O</smiles><smiles>CCOC(=O)c1cc(C2OCC(C)C2C)oc1C</smiles>

$4 a$

$97 \%$

72<smiles>CC(=O)c1cc(C2OC[C@@H](O)[C@H]2O)oc1C</smiles>

$89 \%$

0

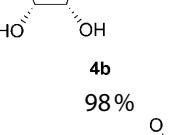

0<smiles>O[C@H]1CO[C@@H](c2cc3c(o2)CCCC3)[C@@H]1O</smiles>

$\mathrm{HO} " \mathrm{OH}$

$4 c$
$89 \%$

0<smiles>CC(=O)c1cc(C2OCC(O)C2CO)oc1C</smiles>

0<smiles>CC(=O)c1cc(C2OC[C@@H](O)[C@@H]2O)oc1C</smiles>

$99 \%$

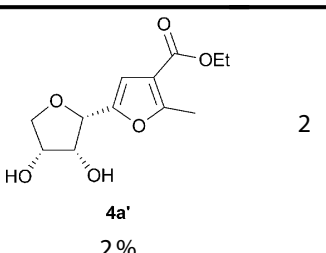

2

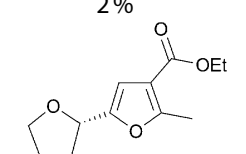

97

$\mathrm{HO}$ " "OH

4a'<smiles>CC(=O)c1cc([C@@H]2OC[C@@H](O)[C@H]2O)oc1C</smiles>

$11 \%$<smiles>CC(=O)c1cc([C@@H]2OC[C@@H](O)[C@H]2O)oc1C</smiles>

91

$\mathrm{HO} " \mathrm{OH}$

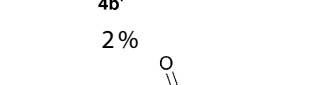

38

HO "OH

$4 c^{\circ}$

$11 \%$

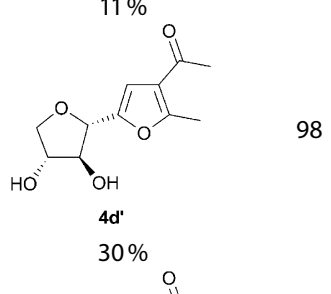

98

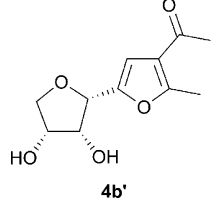

90

$1 \%$

[a] Reaction conditions: carbohydrate ( $10 \mathrm{mmol}), \beta$-dicarbonyl compound (12 mmol), plant-based catalyst $(\mathrm{Zn}+\mathrm{Fe}+\mathrm{Al}=8.0 \% \mathrm{~mol}), \mathrm{SiO}{ }_{2}(500 \mathrm{mg}), 24 \mathrm{~h}$. [b] Proportions determined by ${ }^{1} \mathrm{H}$ NMR spectroscopy. [c] Yield of isolated product. 


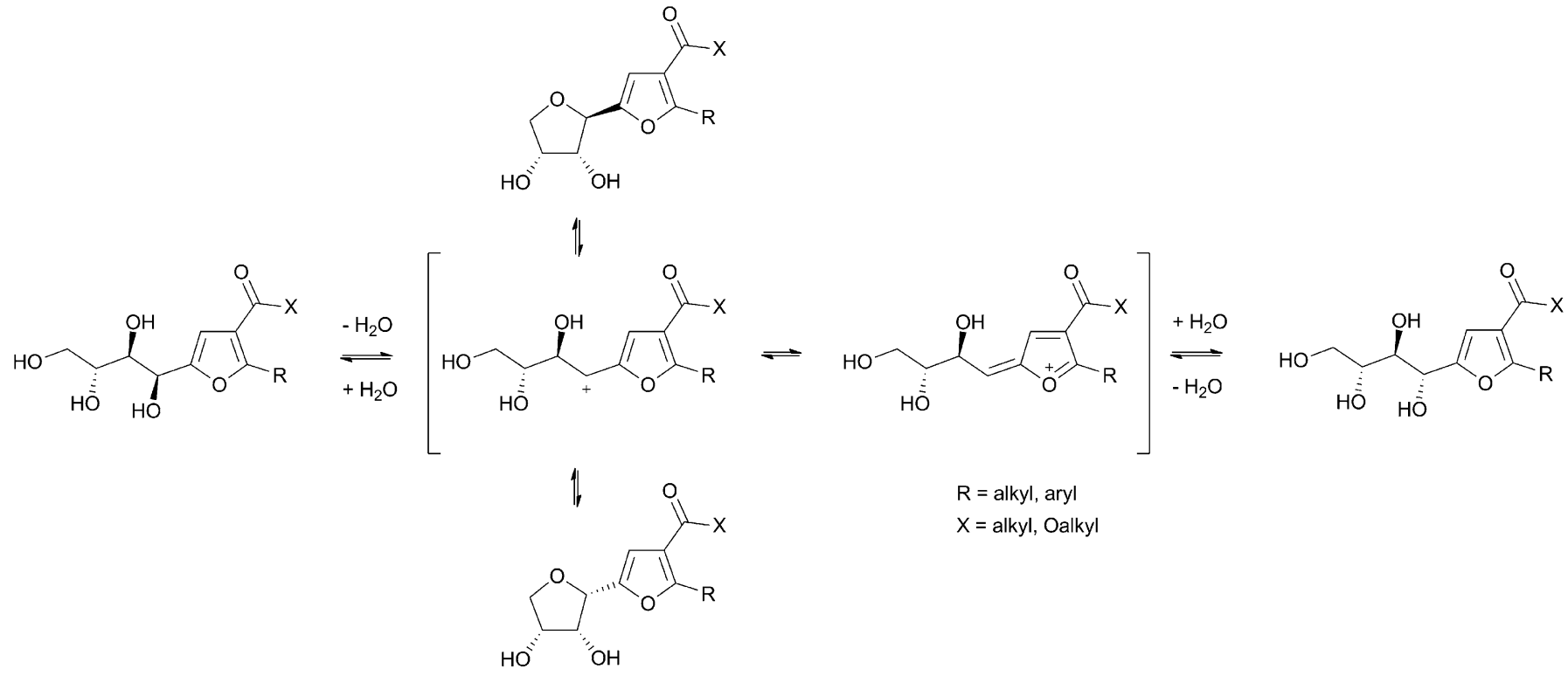

Scheme 3. Epimerization of the uncyclized and cyclized products.

Table 7. Reusability of the plant-based catalyst in the Garcia Gonzalez reaction.

\begin{tabular}{|c|c|c|c|c|c|c|}
\hline \multirow[t]{2}{*}{ Run } & \multirow{2}{*}{$\begin{array}{l}\text { Yield [\%] } \\
3 \mathbf{a}-3 \mathbf{a}^{\prime}\end{array}$} & \multicolumn{5}{|c|}{ Composition [wt $\% \pm$ standard deviation] } \\
\hline & & $\mathrm{Zn}$ & $\mathrm{Fe}$ & $\mathrm{Al}$ & $\mathrm{Cd}$ & $\mathrm{Pb}$ \\
\hline first & 65 & $6.75 \pm 0.026$ & $2.75 \pm 0.042$ & $1.50 \pm 0.016$ & $0.19 \pm 0.0052$ & $0.44 \pm 0.0073$ \\
\hline second & 60 & $6.70 \pm 0.019$ & $2.47 \pm 0.028$ & $1.47 \pm 0.049$ & $0.19 \pm 0.0066$ & $0.44 \pm 0.0020$ \\
\hline third & 58 & $6.70 \pm 0.041$ & $2.38 \pm 0.037$ & $1.45 \pm 0.059$ & $0.19 \pm 0.0037$ & $0.44 \pm 0.0093$ \\
\hline fourth & 55 & $6.68 \pm 0.028$ & $2.34 \pm 0.055$ & $1.45 \pm 0.036$ & $0.19 \pm 0.0040^{[a]}$ & $0.44 \pm 0.0051^{[\mathrm{b}]}$ \\
\hline
\end{tabular}

[a] Complementary ICP-MS analysis revealed that less that $5 \mathrm{ppm}$ of Cd was lost after the four runs. [b] Complementary ICP-MS analysis revealed that less that $5 \mathrm{ppm}$ of $\mathrm{Pb}$ was lost after the four runs.

of $\mathrm{Zn}, \mathrm{Fe}$, and Al. These results thus illustrate the stability of the plant-based catalyst and show that there is no leaching of metallic species during the reaction and workup. Only the amount of iron decreased slightly. No trace amounts of cadmium or lead were detected during ICP-MS analysis of the final products. This result is important because these elements are known to be highly toxic.

\section{Conclusions}

In conclusion, we described the preparation of a novel plantbased Lewis acid catalyst starting form hyperaccumulating plants collected on former mining sites. The conception of this new type of catalyst can contribute to the recycling of mining wastes. The characterization of this biosourced catalyst revealed that it was composed of mono- and polymetallic species, particularly of transition-metal chlorides known for their Lewis acid character, such as $\mathrm{K}_{2} \mathrm{ZnCl}_{4}$. Reproducibility studies showed that the metal content of the catalyst was 4.80 $9.65 \mathrm{wt} \%$ for $\mathrm{Zn}, 1.13-2.95 \mathrm{wt} \%$ for $\mathrm{Fe}$, and $1.10-1.74 \mathrm{wt} \%$ for $\mathrm{Al}$, depending on the localization of the plants used in the preparation of the catalyst. This catalyst proved to be highly efficient in the Garcia Gonzalez reaction by using solid-state methodology without the use of any additive, which improved the green potential of the reaction. Good to excellent yields (up to $98 \%$ ) of polyhydroxyalkyl furans were obtained. The plant-based Lewis acid catalyst showed unusual flexibility in catalyzing the Garcia Gonzalez reaction, as furans with an uncyclized or cyclized alkyl chain were obtained simply by adjusting the reaction temperature. Such an activity was not previously described for the catalysis of this reaction. Finally, this study highlighted the epimerization of uncyclized and cyclized polyhydroxyalkyl furans, which was only hypothetical on some points until now.

\section{Experimental Section}

\section{General methods}

Reagents and solvents were purchased from Sigma-Aldrich and were used without further purification. Flash column chromatography was performed by using Chromagel Carlo Erba Reactifs SDS silica 60A CC 35-70 $\mu \mathrm{m}$. Reactions were monitored by using Merck Kieselgel 60 F254 aluminum. TLC plates were visualized by UV fluorescence $(254 \mathrm{~nm})$ and one of the following: $\mathrm{KMnO}_{4}$, ninhydrin, phosphomolybdic acid solution, or phosphotungstic acid solution. 


\section{Preparation of the polymetallic plant-based catalyst}

Leaves of Noccaea caerulescens and Anthyllis vulneraria were harvested before flowering in Les Avinières, a former zinc mining site in Saint-Laurent-Le-Minier, southern France (same mass of the two plants), air dried, and crushed. The obtained solid $(150 \mathrm{~g})$ was calcined at $400^{\circ} \mathrm{C}$ for $5 \mathrm{~h}$, and the resulting powder $(24 \mathrm{~g})$ was added to $1 \mathrm{M} \mathrm{HCl}$ solution $(100 \mathrm{~mL})$. The solution was heated at $60^{\circ} \mathrm{C}$ and stirred for $2 \mathrm{~h}$. The reaction mixture was filtered through Celite. The resulting solution, composed of different metal chlorides, was then concentrated under vacuum. The catalyst was kept in a desiccator under vacuum.

\section{General procedure for the synthesis of uncyclized polyhy- droxyalkyl furans}

The carbohydrate $(10 \mathrm{mmol})$, plant-based catalyst $(390 \mathrm{mg}$, amount corresponding to $0.40 \mathrm{mmol}$ of $\mathrm{Zn}, 0.19 \mathrm{mmol} \mathrm{Fe}, 0.22 \mathrm{mmol} \mathrm{Al} \mathrm{fol-}$ lowing ICP-MS dosing), and silica $(500 \mathrm{mg}$, Chromagel Carlo Erba Reactifs SDS silica 60 A CC 35-70 $\mu \mathrm{m})$ were mixed by grinding in a mortar. The $\beta$-dicarbonyl compound $(12 \mathrm{mmol})$ was added, and the resulting solid was homogenized with a spatula. The solid was introduced in a sealed tube (Ace glass tube, $10.2 \mathrm{~cm} \times 25.4 \mathrm{~mm}$ ) containing a magnetic stirring bar, and the vessel was heated to $50^{\circ} \mathrm{C}$ in an oil bath for $24 \mathrm{~h}$ until completion of the reaction (TLC monitoring, toluene/acetone $=1: 1$ ). The solid mixture was then washed with ethyl acetate $(2 \times 5 \mathrm{~mL})$ and filtered. The resulting solution was evaporated under reduced pressure to yield a grey powder. This powder was purified by crystallization in hot ethyl acetate to give the uncyclized polyhydroxyalkyl furan as a white solid. The previous catalytic solid (mixture of plant-based catalyst and $\mathrm{SiO}_{2}$ ) was recycled by washing with ethyl acetate and drying in an oven $\left(120^{\circ} \mathrm{C}, 5 \mathrm{~h}\right)$ before being reused in the next run. See the Supporting Information for analytical data.

\section{General procedure for the synthesis of cyclized polyhydrox- yalkyl furans}

The carbohydrate $(10 \mathrm{mmol})$, plant-based catalyst $(390 \mathrm{mg}$, amount corresponding to $0.40 \mathrm{mmol}$ of $\mathrm{Zn}, 0.19 \mathrm{mmol} \mathrm{Fe}, 0.22 \mathrm{mmol}$ Al following ICP-MS dosing), and silica (500 mg, Chromagel Carlo Erba Reactifs SDS silica 60 A CC $35-70 \mu \mathrm{m}$ ) were mixed by grinding in a mortar. The $\beta$-dicarbonyl compound $(12 \mathrm{mmol})$ was added, and the resulting solid was homogenized with a spatula. The solid was introduced in a sealed tube (Ace glass tube, $10.2 \mathrm{~cm} \times 25.4 \mathrm{~mm}$ ) containing a magnetic stirring bar, and the vessel was heated to $85^{\circ} \mathrm{C}$ in an oil bath for $24 \mathrm{~h}$ until completion of the reaction (TLC monitoring, toluene/acetone $=1: 1$ ). The solid mixture was then washed with ethyl acetate $(2 \times 5 \mathrm{~mL})$ and filtered. The resulting solution was evaporated under reduced pressure to yield a brown oil. This oil was purified by flash column chromatography (toluene/ acetone $=1: 1$ ) to yield the cyclized polyhydroxyalkyl furan as an off-white solid, which was recrystallized in hot ethyl acetate. The previous catalytic solid (mixture of plant-based catalyst and $\mathrm{SiO}_{2}$ ) was recycled by washing with ethyl acetate and drying in an oven $\left(120^{\circ} \mathrm{C}, 5 \mathrm{~h}\right)$, before being reused in the next run. See the Supporting Information for analytical data.

\section{Acknowledgements}

The authors would like to thank Agence Nationale de la Recherche (ANR) (11ECOT 011 01), Agence de l'Environnement et de la
Maîtrise de l'Energie (ADEME), and Fond Européen de Développement Régional (FEDER) programs for financial support. Mr. Doyle McKey and Mr. Robert Feldman are acknowledged for proofreading the text.

Keywords: biomass $\cdot$ carbohydrates $\cdot$ green chemistry $\cdot$ plantbased catalysis $\cdot$ waste reuse

[1] a) A. Corma, S. Iborra, A. Velty, Chem. Rev. 2007, 107, 2411-2502; b) P. Gallezot, Chem. Soc. Rev. 2012, 41, 1538-1558; c) J. J. Bozell, G. R. Petersen, Green Chem. 2010, 12, 539-554.

[2] T. Werpy, G. Pedersen, Top Value Added Chemicals from Biomass, US Department of Energy, Oak Ridge, 2005.

[3] A. A. Rosatella, S. P. Simeonov, R. F. M. Frade, C. A. M. Afonso, Green Chem. 2011, 13, 754-793.

[4] D. M. Alonso, S. G. Wettstein, J. A. Dumesic, Green Chem. 2013, 15, $584-$ 595.

[5] M. Dusselier, P. Van Wouwe, A. Dewaele, E. Makshina, B. F. Sels, Energy Environ. Sci. 2013, 6, 1415-1442.

[6] a) F. W. Lichtenthaler, S. Peters, C. R. Chim. 2004, 7, 65-90; b) M. J. Climent, A. Corma, S. Iborra, Green Chem. 2011, 13, 520-540.

[7] F. G. González, Adv. Carbohydr. Chem. 1956, 11, 97-143.

[8] A. K. Misra, G. Agnihotri, Carbohydr. Res. 2004, 339, $1381-1387$.

[9] A. J. Moreno-Vargas, J. Jiménez-Barbero, I. Robina, J. Org. Chem. 2003 , $68,4138-4150$

[10] a) P. Anastas, J. C. Warner, Green Chemistry: Theory and Practice, Oxford University Press, Oxford, 1998; b) R. A. Sheldon, Chem. Soc. Rev. 2012, 41, 1437-1451; c) R. A. Sheldon, I. W. C. E. Arends, U. Hanefeld, Green Chemistry and Catalysis, Wiley-VCH, Weinheim, 2007.

[11] L. Nagarapu, M. V. Chary, A. Satyender, B. Supriya, R. Bantu, Synthesis 2009, 2278-2282.

[12] G. Bartoli, J. G. Fernández-Bolaños, G. Di Antonio, G. Foglia, S. Giuli, R. Gunnella, M. Mancinelli, E. Marcantoni, M. Paoletti, J. Org. Chem. 2007, 72, 6029-6036.

[13] A. J. Hunt, T. J. Farmer, J. H. Clark in Element Recovery and Sustainability, The Royal Society of Chemistry, Cambridge, 2013, pp. 1-28.

[14] a) L. Erdmann, T. E. Graedel, Environ. Sci. Technol. 2011, 45, 7620-7630; b) I. Sohn, Resour. Policy 2005, 30, 259-284; c) N. T. Nassar, R. Barr, M. Browning, Z. Diao, E. Friedlander, E. M. Harper, C. Henly, G. Kavlak, S. Kwatra, C. Jun, S. Warren, M.-Y. Yang, T. E. Graedel, Environ. Sci. Technol. 2012, 46, 1071 -1078; d) R. Sinding-Larsen, F.-W. Wellmer in Non-Renewable Resource Issues (Eds.: R. Sinding-Larsen, F.-W. Wellmer), Springer Netherlands, 2012, pp.1-19; e) T. E. Graedel, R. Barr, C. Chandler, T. Chase, J. Choi, L. Christoffersen, E. Friedlander, C. Henly, C. Jun, N. T. Nassar, D. Schechner, S. Warren, M.-y. Yang, C. Zhu, Environ. Sci. Technol. 2012, 46, 1063-1070.

[15] a) U. Lahl, K. A. Hawxwell, Environ. Sci. Technol. 2006, 40, 7115-7121; b) M. Wilson, M. Schwarzman, Environ. Health Perspect. 2009, 117, 1202 1209 ; c) K. J. M. Matus, J. B. Zimmerman, E. Beach, Environ. Sci. Technol. 2010, 44, 6022-6023.

[16] a) Catalysis without Precious Metals (Ed.: R. M. Bullock), Wiley-VCH, Weinheim, 2010; b) S. Enthaler, K. Junge, M. Beller, Angew. Chem. Int. Ed. 2008, 47, 3317-3321; Angew. Chem. 2008, 120, 3363-3367.

[17] C. W. N. Anderson in Element Recovery and Sustainability, The Royal Society of Chemistry, Cambridge, 2013, pp. 114-139.

[18] a) C. Grison, J. Escarré, WO2011/064462A1; PCT/FR2009/052312, 2011; b) C. Grison, J. Escarré, patent references: WO2011/064487A1; PCT/ FR2010/052451; CA2781832A1; EP2504096A1, 2011; c) V. Escande, L. Garoux, C. Grison, Y. Thillier, F. Debart, J.-J. Vasseur, C. Boulanger, C. Grison, Appl. Catal. B 2014, 146, 279-288; d) G. Losfeld, V. Escande, T. Jaffré, L. L'Huillier, C. Grison, Chemosphere 2012, 89, 907-910.

[19] A. Bhargava, F. F. Carmona, M. Bhargava, S. Srivastava, J. Environ. Manage. 2012, 105, 103-120.

[20] I. Raskin, B. D. Ensley, Phytoremediation of Toxic Metals, Using Plants to Clean Up the Environment, Wiley, New York, 2000.

[21] R. L. Chaney, C. L. Broadhurst, T. Centifanty, J. S. Angle, Y. M. Li, C. A. Peters, R. J. Rosenberg, A. P. Davis, A. J. M. Baker, R. D. Reeves, Abstracts 
of the International Conference on the Biogeochemistry of Trace Elements, Chihuahua, Mexico, 2009.

[22] B. Robinson, M. Leblanc, D. Petit, R. Brooks, J. Kirkman, P. H. Gregg, Plant Soil 1998, 203, 47-56.

[23] a) G. Losfeld, P. V. de La Blache, V. Escande, C. Grison, Green Chem. Lett. Rev. 2012, 5, 451-456; b) G. Losfeld, V. Escande, P. Vidal de La Blache, L. L'Huillier, C. Grison, Catal. Today 2012, 189, $111-116$; c) Y. Thillier, G. Losfeld, V. Escande, C. Dupouy, J.-J. Vasseur, F. Debart, C. Grison, RSC Adv. 2013, 3, 5204-5212.

[24] a) P. Laszlo, A. Mathy, Helv. Chim. Acta 1987, 70, 577-586; b) A. Nasreen, Synlett 2001, $1341-1342$.
[25] W. J. W. Watson, Green Chem. 2012, 14, $251-259$.

[26] a) A. Gómez Sánchez, A. Rodríguez Roldán, Carbohydr. Res. 1972, 22, 53-62; b) A. P. Kozikowski, G. Q. Lin, J.P. Springer, Tetrahedron Lett. 1987, 28, $2211-2214$.

[27] K. Conrow, J. Org. Chem. 1966, 31, 1050-1053. 